\title{
ELEKTRONINIS SVEIKATOS IૃRAŠAS IR TEISINĖ APLINKA: ESAMA SITUACIJA BEI PROBLEMOS
}

\author{
Darius Štitilis \\ Mykolo Romerio universiteto Socialinių technologijų fakulteto \\ Skaitmeninių technologijų institutas \\ Ateities g. 20, LT-08303 Vilnius, Lietuva \\ Telefonas (8 5) 2714571 \\ Elektroninis paštas stitilis@mruni.eu
}

Straipsnis parengtas pagal mokslinio tyrimo, finansuojamo Europos socialinio fondo lèšomis pagal visuotinès dotacijos priemonę, medžiagą

(projektas „E-sveikatos plètros integruotos transformacijos: suinteresuotųjų pusių tinklo perspektyva“, projekto kodas VP1-3.1-ŠMM-07-K-02-029).

Pateikta $2014 \mathrm{~m}$. vasario $13 \mathrm{~d}$., parengta spausdinti $2014 \mathrm{~m}$. vasario $28 \mathrm{~d}$.

doi:10.13165/SPV-14-1-6-05

\section{Santrauka}

Elektroniniai sveikatos įrašai ịvairiose valstybèse plinta dideliu greičiu. Tačiau tam turi būti sukurta tinkama teisine aplinka. Straipsnyje nagrinèjami kai kurie svarbiausi elektroninių sveikatos įrašu teisinès aplinkos elementai (elektroninio sveikatos ịrašo reglamentavimas strateginiuose dokumentuose, elektroninio sveikatos įrašo teisine galia), taip pat elektroninès sveikatos teisinio reguliavimo srityje pažangiausiu valstybiu bei ES teisès aktai, reglamentuojantys elektroninius sveikatos įrašus, lyginant su Lietuvos teisine baze bei analizuojant Lietuvos teisini reguliavima atitinkamoje srityje. Privatumo ir asmens duomenu apsaugos teisinio reguliavimo Lietuvoje klausimai, kiek tai susiję su elektroniniais sveikatos įrašais, nagrinèjami atsižvelgiant ị atitinkamas Europos Komisijos rekomendacijas.

Reikšminiai žodžiai: elektroninis sveikatos įrašas, teisinis reguliavimas.

\section{Ivadas}

Informacinių technologijų plètra, informacijos perkèlimas j̇ elektroninę erdvę didina informacinių procesų ir veiklos kokybę, užtikrina geresnị konkurencingumą bei efektyvumą. Viena iš sričių - sveikatos paslaugų teikimas elektronineje erdveje. Elektroninis sveikatos ịrašas (angl. electronic health record) - tai besivystanti koncepcija, apibrèžiama kaip elektroninès sveikatos informacijos rinkimas apie individualų pacientą ar tam tikrą grupę žmonių ${ }^{1}$.

1 Gunter, T. D.; Terry, N. P. The Emergence of National Electronic Health Record Architectures in the United

States and Australia: Models, Costs, and Questions. Journal of Medical Internet Research. 2005, 7(1). 
Atsirandantys elektroninio sveikatos įrašo modeliai kelia nemažai iššūkių sveikatos priežiūros sistemoms, gydytojams ir įstatymų leidejjams. Vieni iš didžiausių iššūkių - teisinei sistemai, kadangi įstatymų leidejjams kyla būtinybẻ keisti ar pildyti tradicinị esamą sveikatos teisinį reguliavimą, suteikiant teisę tvarkyti elektroninius sveikatos įrašus, išrašyti elektroninius receptus ir pan. Elektroninės sveikatos ịrašas vertinamas kaip pagrindinis e. sveikatos elementas, nuo kurio priklauso e. sveikatos funkcionavimas valstybèje. Todèl elektroninio sveikatos įrašo teisinè aplinka - vienas iš svarbiausių institutų sveikatos priežiūrai konverguojant ị elektroninę erdvę. Lietuvoje šie procesai dar tik prasideda, todėl Lietuvai svarbu ịsivertinti esamą teisinio reguliavimo situaciją ir, esant poreikiui, perimti gerąją elektroninių sveikatos įrašų teisinio reguliavimo praktiką iš ES bei šioje srityje lyderiaujančių ir nemažą patirtị sukaupusių atitinkamų ES valstybių.

Todèl šio mokslinio straipsnio tikslas - išanalizuoti elektroninio sveikatos įrašo teisinị reguliavimą, kiek tai susiję su strateginiais bei pamatiniais teisès aktais, taip pat teisès aktais privatumo apsaugos srityje, pasiremiant gerąja ES ir ES valstybių praktika.

Mokslinio tyrimo objektas - e. sveikatos teisinis reguliavimas (ES, ES valstybėse ir Lietuvoje), kiek tai susiję su elektroniniu sveikatos ịrašu.

Temos ištirtumas - užsienyje pastaraisiais metais pasirodė nemažai mokslinių publikacijų apie elektroninius sveikatos ịrašus. Šią temą nagrinèjo šie užsienio mokslininkai: T. D. Gunter, N. P. Terry, P. Kierkegaard, D. F. Sitti, H. Singh ir kiti. Kai kuriuose šių mokslininkų straipsniuose vienu ar kitu aspektu aptariami teisiniai elektroninio sveikatos įrašo aspektai, tačiau tai daroma fragmentiškai, trūksta sisteminimo ir apibendrinimų. Tuo tarpu Lietuvos mokslininkų darbuose elektroninis sveikatos įrašas kaip institutas nebuvo nagrinètas. Teisiniai instituto aspektai taip net nebuvo analizuoti.

Metodologija - tyrimui atlikti taikyti keli skirtingi metodai: tirdamas elektroninio sveikatos įrašo teisinị reguliavimą ir atitinkamas susijusias teisès normas, autorius pasitelkè lyginimo metodą. Galiojančio elektroninio sveikatos įrašo teisinio reguliavimo nustatymui taikytas empirinis teisinių dokumentų analizès metodas. Šis metodas leidžia ištyrus oficialius dokumentus tiksliai nustatyti ir aprašyti atitinkamo santykio galiojantị teisinị reguliavimą. Naudodamas mokslinès literatūros šaltinius autorius taikẻ dedukcijos metodą, leidžiantį daryti pakankamai patikimas išvadas. Sąvokų tyrimui autorius pasitelkè naujausią mokslinę literatūrą.

Rezultatai - tyrimas atskleidè, jog elektroninio sveikatos įrašo teisinè aplinka sparčiai vystosi tiek plètojant ES strateginị reguliavimą, tiek užsienio valstybèse, tiek ir Lietuvoje. Lietuvoje, nepaisant išsamių strateginių teisès normų, vis dar trūksta elektroninio sveikatos įrašo teisinio reguliavimo pamatinemis teisès normomis, ypač dèl elektroninio sveikatos ịrašo teisinès galios įtvirtinimo.

Tyrimo ribotumas - nors elektroninio sveikatos įrašo teisinio reguliavimo analizè gali būti atliekama lyginant ịvairaus lygmens teisès aktus, tačiau tyrimas atliktas lyginant ir komentuojant tik pagrindinius, strateginius teisès aktus - strategijas, ịstatymus. Tyrimo metu taip pat nebuvo detaliai analizuojamas teisės normų elektroninio sveikatos įrašo srityje igyvendinimas.

Praktinè reikšmė - tyrimo rezultatai gali būti pritaikomi kuriant naujas teisès normas ar atliekant egzistuojančių teisès normų pakeitimus, kiek tai susiję su elektroninių sveikatos įrašų sistema, įskaitant pamatinị teisinị reguliavimą bei galimas teisès normas identifikavimo srityje.

Originalumas / vertingumas - straipsnyje pristatomas tyrimas yra naujas Lietuvoje. Elektroninius sveikatos įrašus reglamentuojančių strateginių, pamatinių bei su privatumo apsauga susijusių teisès aktų analizė anksčiau atlikta nebuvo. Tyrimo rezultatai užpildo šią tuštumą.

Tyrimo tipas - tyrimo (įskaitant lyginamąjị) pristatymas, požiūrio pristatymas. 


\section{Elektroninis sveikatos ịrašas ir strateginis e. sveikatos reguliavimas}

P. Kierkegaard teigia, kad, be elektroninio sveikatos įrašo sąvokos, dažnai alternatyviai vartojama ir elektroninio medicininio įrašo sąvoka. Tačiau šie terminai iš principo skiriasi ir neturètų būti maišomi. Elektroniniame medicininiame įraše, kaip ịprasta, atitinkamos medicininès priežiūros įstaigos saugoma paciento informacija, tuo tarpu elektroniniame sveikatos įraše saugoma informacija apie pacientą iš visų sveikatos priežiūros ịstaigų ${ }^{2}$. Toliau šiame straipsnyje bus remiamasi Kierkegaard pateikta pozicija dèl elektroninio sveikatos ịrašo ir elektroninio medicininio įrašo atskyrimo.

Vis dèlto kaip yra apibrèžiamas elektroninis sveikatos įrašas? $2008 \mathrm{~m}$. patvirtintoje Europos Komisijos rekomendacijoje dèl tarpvalstybinio elektroninių sveiktos įrašų sistemų suderinamumo „elektroninis sveikatos įrašas“ apibrèžiamas kaip išsamus elektroninès formos medicininis įrašas ar panaši elektroninès formos dokumentacija apie praeities ir esamą individo sveikatos būklę, kai užtikrinama šių duomenų prieiga medicininio gydymo ir kitais susijusiais tikslais ${ }^{3}$. Identiškai elektroninị sveikatos įrašą apibrèžia ir Bendrosios duomenų apsaugos direktyvos 29 straipsnio darbo grupe $\dot{e}^{4}$.

Mokslinejje literatūroje autoriai T. D. Gunter, N. P. Terry elektroninį sveikatos įrašą apibrèžia kaip elektroninès sveikatos informacijos rinkimą apie individualų pacientą ar tam tikrą grupę žmonių 5 .

Ivairiuose kituose šaltiniuose elektroninio sveikatos įrašo apibrèžimai skiriasi, tačiau ju esmè vienoda - tai renkama ir saugoma elektroninè informacija apie pacientą bei jo sveikatą, nustatyta tvarka elektroniniu būdu prieinama tiek sveikatos priežiūros ịstaigų darbuotojams, tiek pačiam pacientui.

Viena iš aktualiausių pastarųjų metų teisinio reguliavimo problemų, susijusių su elektroniniais sveikatos įrašais, yra ta, kad tradicinis sveikatos srities teisinis reguliavimas nenumate elektroninio sveikatos įrašo instituto. Istoriškai buvo reglamentuojama, kad sveikatos priežiūros paslaugos teikiamos tradiciniu būdu, o informacija apie pacientą saugoma atitinkamoje sveikatos įstaigoje tradiciniuose rašytiniuose dokumentuose. Toks teisinis reguliavimas ilgą laiką buvo taikomas tiek Europoje, tiek JAV. Tuo tarpu elektroninis sveikatos įrašas iš principo keičia informacijos apie pacientą bei jo sveikatą rinkimo bei saugojimo mechanizmus, atsiranda vienas elektroninès informacijos saugojimo formatas, kuris potencialiai turètų būti vienodas ne tik atitinkamoje valstybeje, bet ir visoje Europos Sąjungoje.

Taigi, tradiciniam sveikatos teisiniam reguliavimui, atsirandant elektroniniam sveikatos įrašui, tenka iššūkis ir kartu naujos galimybès.

2 Kierkegaard, P. Electronic health record: wiring Europe's healthcare.Computer law \& security review. 2011, 27 [interaktyvus]. [žiūrèta 2013-11-28]. <http://www.sciencedirect.com/science/article/pii/S02 $67364911001257>$, p. 503.

3 Commission Recommendation of 2 July 2008 on crossborder interoperability of electronic health record systems [interaktyvus]. [žiūrèta 2013-11-28]. < http://eur-lex.europa.eu/LexUriServ/LexUriServ. do?uri=OJ:L:2008:190:0037:0043:EN:PDF >, 3 c).

4 Working document on the processinf of personal data relating to health in electronic health records (EHR). WP 131, 2007 [interaktyvus]. [žiūrèta 2013-12-26]. <http://ec.europa.eu/justice/policies/ privacy/docs/wpdocs/2007/wp131_en.pdf>, p. 4.

5 Gunter, T. D.; Terry, N. P., supra note 1, p. 1.

6 Dumortier, J.; Verhenneman, G. Legal regulations of electronic health record: a prerequisite or an unavoidable by-product? - The egal aspects of electronic health records in Europe and the US analysed. (December 22, 2011). ICRI Research Paper No. 5 [interaktyvus]. [žiürèta 2013-11-28]. <http://papers. ssrn.com/sol3/papers.cfm?abstract_id=1975758>, p. 3 . 
Vienas iš pagrindinių atitinkamos srities teisinio reguliavimo dokumentų - strategijos. Tai kertiniai teisès aktai, kurių pagrindu plètojama atitinkamos srities teisinė bazè. E. sveikatos srityje strateginiai dokumentai - strategijos taip pat labai svarbūs.

ES elektroninio sveikatos įrašo institutas pradètas minèti būtent strateginiuose dokumentuose. Šie dokumentai davè impulsą elektroninio sveikatos įrašo teisinio reguliavimo iniciatyvoms nacionaliniu lygmeniu.

Direktyva 2011/24/ES dèl pacientų teisių ị tarpvalstybines sveikatos priežiūros paslaugas igyvendinimo, kaip teigia P. Kierkegaard, pirmą kartą Europos istorijoje nustato e. sveikatos teisinio reguliavimo modeli, taip skatindama vystyti ir pavirtinti elektroninius pacientų irašus visoje Europoje ${ }^{7}$. Nors reikia paminèti, kad direktyvoje tiesiogiai elektroniniai sveikatos įrašai neminimi - direktyvoje pasisakoma už e. sveikatos sistemų ir paslaugų sąveiką: „siekti užtikrinti Europos e. sveikatos sistemų ir paslaugų bei sąveikių taikomųjų programų tvarią ekonominę ir socialinę naudą, kad būtų užtikrintas aukštas patikimumo ir saugumo lygis, gerinamas priežiūros tęstinumas ir užtikrinta galimybė naudotis saugiomis ir aukštos kokybės sveikatos priežiūros paslaugomis"8.

2012 m. gruodžio 6 d. Europos Komisija patvirtino komunikatą dèl e. sveikatos veiksmų plano 2012-2020 m. - Inovatyvi sveikatos priežiūra 21 amžiuje $^{9}$. Nors komunikate tiesiogiai elektroniniai sveikatos įrašai neminimi, tačiau nurodoma, jog „Siekiant Europoje diegti e. sveikatos sistemas, labai svarbu pašalinti teisines kliūtis. Direktyva dèl pacientų teisių i tarpvalstybines sveikatos priežiūros paslaugas ịgyvendinimo tą tikslą padès pasiekti, nes joje išaiškinamos pacientų teisès gauti tarpvalstybinę sveikatos priežiūrą, ịskaitant nuotoliniu būdu (naudojantis telemedicinos paslaugomis) “10.

Taip pat paminètina, kad dar 2008 m. patvirtintoje Europos Komisijos rekomendacijoje dèl tarpvalstybinio elektroninių sveiktos įrašų sistemų suderinamumo ${ }^{11}$ numatomi etapai, kurių Šalys narès turi imtis, siekiant įkurti elektroninių sveikatos įrašų sistemas, suderinamas visoje Europos Sąungoje. Šios rekomendacijos tikslas - užtikrinti visos ES e. sveikatos sistemų suderinamumą iki $2015 \mathrm{~m}$. galo ${ }^{12}$. Rekomendacija skatina priimti atitinkamus teisès aktus, reglamentuojančius visose Valstybėse narėse suderinamus elektroninius sveikatos ịrašus. Priimant tokius teisès aktus, vertètų atkreipti dėmesị $\mathfrak{i}$ asmens duomenų, susijusių su sveikata, jautrumą bei užtikrinti atitinkamus saugiklius, susijusius su vienos iš pagrindinių žmogaus teisių - teisès ị privatumą - apsauga ${ }^{13}$.

Kierkegaard, P., supra note 2, p. 505.

8 Europos Parlamento ir Tarybos $2011 \mathrm{~m}$. kovo 9 d. direktyva 2011/24/ES dèl pacientų teisių ị tarpvalstybines sveikatos priežiūros paslaugas igyvendinimo [interaktyvus]. [žiūrèta 2013-11-28]. < http:// eur-lex.europa.eu/LexUriServ/LexUriServ.do?uri=OJ:L:2011:088:0045:0065:lt:PDF>, 14 str. 2 d. a)

9 Communication from the Commission to the European Parliament, the Council, the European Economic and Social Committee and the Committee of the Regions „eHealth Action Plan 2012-2020 - Innovative healthcrefor the 21st century. Brussels, 6.12.2012, COM(2012) 736 final [interaktyvus]. [žiūrèta 2013-1128]. <http://eur-lex.europa.eu/LexUriServ/LexUriServ.do?uri=COM:2012:0736:FIN:LT:PDF>.

10 Communication from the Commission to the European Parliament, the Council, the European Economic and Social Committee and the Committee of the Regions „eHealth Action Plan 2012-2020 - Innovative healthcrefor the 21st century. Brussels, 6.12.2012, $\operatorname{COM(2012)~} 736$ final, supra note 9, p. 9.

11 Commission Recommendation of 2 July 2008 on crossborder interoperability of electronic health record systems, supra note 3 .

12 Ibid., preambules $9 \mathrm{p}$.

13 Kierkegaard, P., supra note 1, p. 506. 
Kai kuriose Europos valstybėse elektroninio sveikatos įrašo „itteisinimas“ir reguliavimas buvo skatinamas nacionalinių vyriausybių ${ }^{14}$, elektroninis sveikatos įrašas buvo pradètas minèti ir strateginiuose dokumentuose.

Airijos $2004 \mathrm{~m}$. nacionalineje sveikatos informacijos strategijoje ${ }^{15}$ elektroniniam sveikatos įrašui skiriamas atskiras skyrius. Strategijoje aptariama elektroninio sveikatos ịrašo samprata ir pateikiamos koncepcinès elektroninio sveikatos įrašo prielaidos. Strategijoje nurodoma, kad turint omenyje elektroninio sveikatos įrašo sąveikumą, reikalingas nacionalinis, koordinuotas ir integruotas požiūris. Atskirų sveikatos priežiūros ịstaigų informacinès sistemos turi būti pakeistos, atsižvelgiant ị nacionalinị aspektą ${ }^{16}$.

Estijos nacionaliniame sveikatos plane ${ }^{17}$ elektroninis sveikatos įrašas taip detaliai kaip Airijos atveju nereglamentuojamas, bet plane užsimenama, kad Estija palaiko inovatyvius sprendimus medicinoje. Nurodoma, kad Estijoje bus įdiegta nacionalinè e. sveikatos informacijos sistema: skaitmeninès pacientų istorijos, skaitmeniniai įrašai bei skaitmeniniai receptai ${ }^{18}$.

Nuo 1990 m. Danija naudojo nacionalines IT strategijas tam, kad nukreiptų šali link transformacijos procesų, panaudojant IT teikiant aukštos kokybės sveikatos priežiūros paslaugas. Geriausias to pavyzdys - Danijos Vyriausybès nustatytas privalomas elektroninių sveikatos įrašų naudojimas ${ }^{19}$.

Pateikti pavyzdžiai, susiję su nacionalinėmis sveikatos strategijomis, kaip parodè atliktas užsienio valstybių sveikatos strategijų tyrimas, liudija, kad tiek ES, tiek užsienio valstybių strateginiuose dokumentuose dèmesys skiriamas ir elektroniniam sveikatos įrašui. Nors tai nèra visas be išimties užsienio valstybes apimanti praktika, elektroninių sveikatos įrašų reglamentavimas strateginiuose dokumentuose įvardintinas kaip siektinas pavyzdys, inicijuojantis atitinkamo teisinio reguliavimo, susijusio su elektroniniais sveikatos įrašais, įtvirtinimą ir kituose nacionaliniuose teisès aktuose, reglamentuojant jau konkrečius su elektroniniu sveikatos įrašu susijusius aspektus (teisinę galią, privatumo apsaugą, saugumą, prieigą, identifikavimą ir kt.).

Lietuva priklauso toms valstybėms, kurios savo strateginiuose dokumentuose mini elektroninị sveikatos įrašą. Lietuvos e. sveikatos 2007-2015 metų plètros strategijoje ${ }^{20}$ tarp sąvokų išskiriamas ir elektroninis sveikatos įrašas. Elektroninis sveikatos įrašas strategijoje apibrěžiamas kaip integralus visuminis ị pacientą orientuotas sveikatos įrašas, sudarantis e. sveikatos sistemos pagrindą. Kiti įrašai - elektroninis paciento įrašas (EPI), elektroninė ligos istorija (ELI), elektroninis medicininis ịrašas (EMI) iš esmès reiškia dalinị elektroninị sveikatos įrašą, padarytą sveikatos priežiūros ịstaigoje ar farmacijos įmonèje, vykdant epi-

14 Dumortier, J.; Verhenneman, G., supra note 1, p. 2.

15 Health Information: a National Strategy. Ireland, 2004 [interaktyvus]. [žiūrèta 2013-11-28]. <http:// www.dohc.ie/publications/pdf/nhis.pdf?direct $=1>$.

$16 \quad$ Ibid., p. 58.

17 National Health Plan. Estonia [interaktyvus]. [žiūrèta 2013-12-16]. <http://www.sm.ee/fileadmin/ meedia/Dokumendid/Tervisevaldkond/Rahvatervis/RTA/ERTA_english.pdf>.

18 Ibid., p. 6.

19 Kierkegaard, P. eHealth in Denmark: A Case Study. Journal of Medical Systems. 2013, October [interaktyvus]. [žiūretta 2013-11-28]. < http://download.springer.com.skaitykla.mruni.eu/static/ pdf/56/art\%253A10.1007\%252Fs10916-013-9991-y.pdf?auth66=1385807911_a0f9c2f3f540a719a823 90f3871c7440\&ext $=. p d f>$, p. 5 .

20 Lietuvos e. sveikatos 2007-2015 metu plètros strategija. 2007 m. spalio 9 d. Lietuvos Respublikos sveikatos apsaugos ministro įsakymas Nr. V-811 [interaktyvus]. [žiūrèta 2013-12-16]. <http://www3. lrs.lt/pls/inter3/dokpaieska.showdoc_l?p_id=306637\&p_tr2=2>. 
zodinę sveikatos priežiūrą ${ }^{21}$. Strategijoje numatyta viena iš strategijos iggyvendinimo pagrindinių krypčių - kurti ir plètoti e. sveikatos sistemos pagrindą - elektroninị sveikatos įrašą.

Lietuvos e. sveikatos sistemos 2009-2015 metų plètros programoje $\mathrm{e}^{22}$ elektroniniam sveikatos įrašui taip pat skiriama nemažai dèmesio. Šis įrašas programoje vadinamas elektronine sveikatos istorija. Programoje elektroninė sveikatos istorija apibrèžiama kaip elektronine forma kaupiami duomenys apie ankstesnę bei dabartinę paciento fizinę ir psichinę sveikatos būklę, užtikrinantys galimybę lengvai gauti šiuos duomenis teikiant sveikatinimo paslaugas ir kitiems glaudžiai susijusiems tikslams ${ }^{23}$. Be elektroninès sveikatos istorijos, programoje minima ir elektroninè medicininè istorija, kuri suprantama kaip vienoje sveikatos įstaigoje elektroniniu būdu kaupiami sveikatos duomenys.

Šioje programoje deklaruojamas tikslas diegti e. sveikatos paslaugas, kurios apima ir elektroninio sveikatos įrašo ịteisinimą ir diegimą. Paminètina programos 35.1.3 nuostata, pagal kurią e. sveikatos paslaugų ir bendradarbiavimo infrastruktūra turi būti kuriama remiantis sprendimais, sudarančiais sąlygas techniniam ir semantiniam sistemų sąveikumui bei suderinamumui nacionaliniu ir tarptautiniu mastu.

Taigi, viena iš strateginių sveikatos srities dokumentų nuostatų - dèl elektroninio sveikatos įrašo. Tokia praktika paplitus tiek ES, tiek užsienio valstybių strateginiuose dokumentuose, Lietuvoje ši praktika taip pat egzistuoja. Lietuvos e. sveikatos strateginiuose dokumentuose elektroniniam sveikatos įrašui skiriama nemažai dėmesio, taip sukuriant pagrindą tolesniam teisiniam reguliavimui pamatinemis ir kitomis normomis.

\section{Elektroninio sveikatos ịrašo teisinès galios problema}

D. F. Sittig bei H. Singh teigia, kad vienos iš aktualiausių problemų dẻl elektroninių sveikatos įrašų - teisinès problemos ${ }^{24}$. Autoriaus nuomone, elektroninio sveikatos įrašo teisinès galios problematika - viena iš aktualesnių teisinių problemų sričių. Galima pasitelkti analogiją su elektroniniu parašu. Kaip elektroninis parašas buvo ịteisintas technologijų nepripažinusiose teisinèse sistemose, taip ir elektroninis sveikatos įrašas turètų būti ịtvirtinamas teisinėse sistemose. Elektroninis parašas daugelio valstybių teisés aktuose buvo įtvirtinamas pamatinių teisès normų lygiu, t. y. įstatymuose. Ne išimtis ir Lietuva - $2000 \mathrm{~m}$. buvo priimtas Lietuvos Respublikos elektroninio parašo įstatymas. Tuo tarpu vienos iš svarbiausių ịstatymo normų - susijusios su elektroninio parašo teisine galia plačiąja prasme - Lietuvos Respublikos elektroninio parašo įstatymo projekto paaiškinamajame rašte teigiama, kad "projekto centrinè dalis yra 8 straipsnis „Elektroninio parašo teisine galia “25. Svarbu paminèti, kad šiame moksliniame straipsnyje autorius nesilaiko pozicijos, jog elektroninio sveikatos ịrašo teisinè galia turètų būti ịtvirtinta atskirame ịstatyme (kaip kad elektroninio parašo

${ }^{21}$ Lietuvos e. sveikatos 2007-2015 metu plètros strategija. 2007 m. spalio 9 d. Lietuvos Respublikos sveikatos apsaugos ministro įsakymas Nr. V-811 [interaktyvus]. [žiürèta 2013-12-16]. <http://www3. lrs.lt/pls/inter3/dokpaieska.showdoc_l?p_id=306637\&p_tr2=2>, 3 p. 2 p.

22 E. sveikatos sistemos plètros 2009-2015 metų programa. Lietuvos Respublikos sveikatos ministro 2010 m. vasario 22 d. ịsakymas Nr. V-151 [interaktyvus]. [žiūrèta 2013-11-28]. <http://www3.lrs.lt/ pls/inter3/dokpaieska.showdoc_l?p_id=365921\&p_tr2=2>.

$23 \quad$ Ibid., 3 p. 2 p.

24 Sittig D. F.; Singh, H. Legal, Ethical, and Financial Dilemmas in Electronic Health Record Adoption and Use. Pediatrics, 2011, 127(4) [interaktyvus]. [žiūrèta 2013-12-25]. <http://www.ncbi.nlm.nih.gov/ pmc/articles/PMC3065078/>, p. 1.

25 Lietuvos Respublikos elektroninio parašo ịstatymo projekto paaiškinamasis raštas [interaktyvus]. [žiūrèta 2013-12-25]. <http://www3.lrs.lt/pls/inter3/dokpaieska.showdoc_l?p_id=101575>. 
atveju), šio tyrimo kontekste svarbus pats teisinès galios įtvirtinimo pamatinèmis teisès normomis faktas.

Kaip elektroninio sveikatos įrašo teisinès galios klausimai sprendžiami užsienio valstybėse? Paminètina, kad Europoje yra taikomi trys skirtingi elektroninio sveikatos įrašo modeliai ${ }^{26}$ :

- Centralizuoti elektroniniai sveikatos registrai, kai ํkuriamas centrinis registras. Šis modelis vadinamas skandinaviškuoju modeliu. Jị yra igyvendinusi ir Estija.

- Decentralizuotas elektroninių sveikatos įrašų modelis, kai sveikatos duomenys ir toliau tvarkomi atskirai kiekvieno sveikatos paslaugų teikejjo, tačiau sistemos yra sujungtos su nacionaliniu apsikeitimų tašku. Per ši apsikeitimų tašką sveikatos priežiūros paslaugų teikèjas gali pasiekti kitus sveikatos ịrašus.

- Prancūziškas „Dossier Médical Personnel“ modelis, kai pacientas pasirenka sveikatos paslaugų teikejją tam, kad tvarkytų jo asmeninị sveikatos įrašą.

Viena iš labiausiai e. sveikatos teisiniame reguliavime pažengusių valstybių - Estija, ji, kaip jau minèta, yra pasirinkusi centralizuotą elektroninio sveikatos įrašo modelị. $2007 \mathrm{~m}$. gruodžio $20 \mathrm{~d}$. Estijos parlamentas prième įstatymą dèl sveikatos paslaugų organizavimo pakeitimo (angl. Amending the Health Services Organisation Act ${ }^{27}$ ). Šis istatymas numate teisinius pagrindus vystyti e. sveikatos projektus, tokius kaip Elektroninè sveikatos kortelè (angl. Electronics Health Record), Skaitmeninis atvaizdas (angl. Digital image), Skaitmeninis registravimas (angl. Digital Registration). Naujojo įstatymo tikslas yra unifikuoti informacines sistemas ị vieną centrinę Sveikatos informacinę sistemą. Pagrindine šio îstatymo ideja yra igalinti skirtingų medicinos dokumentų apdorojimą elektronine forma. İstatymas numato, kad sveikatos priežiūros paslaugų teikejjai privalo teikti duomenis ị elektroninę sveikatos kortelę. Toks duomenų teikimas pagal įstatymą yra privalomas ${ }^{28}$.

Kita užsienio valstybè, turinti didelę e. sveikatos teisinio reguliavimo praktiką - Vokietija. Dar 2003 m. Vokietijos Viešojo sveikatos draudimo pakeitimo įstatymas numatè pagrindines normas modernizuoti informacijos apdorojimą Vokietijos sveikatos sistemoje. Buvo nuspręsta ịsteigti priskirtą infrastruktūrą sveikatos telematikai Vokietijoje. Nors Vokietijoje yra pasirinktas decentralizuotas modelis, vienos iš pagrindinių teisès aktų nuostatų susijusios su elektronine sveikatos kortele. Elektroninè sveikatos kortelè federaliniu lygiu reglamentuojama V Socialiniame kodekse. Pagal ịstatymą, kortelė yra kaip priemonė valdyti asmeninius medicininius duomenis. Atitinkami duomenys kortelèje gali būti tvarkomi privalomai ar pasirinktinai. Privačių asmens duomenų apsaugojimo tikslu ịstatymas nustato asmenų teises. Piliečių teisès ir duomenų privatumas teisiškai užtikrinamas gaunant piliečio sutikimą (jis turi būti dokumentuojamas Elektronineje sveikatos korteleje). Šiame sutikime nurodoma, kas gali ir kas negali prieiti prie paciento duomenų, taip pat informacija apie priejimų informacijos saugojimą (mažiausiai 50 prieigų informacija turi būti saugoma) ${ }^{29}$.

Airijoje e. sveikatos sriti reglamentuoja Sveikatos informacijos įstatymas (angl. Health information bill). Tokiam ịstatymo būtinybè buvo numatyta dar $2001 \mathrm{~m}$. Nacionalinèje sveikatos strategijoje ir $2004 \mathrm{~m}$. Pagrindiniai nustatyti įstatymo tikslai yra šie:

- Nustatyti teisès normas, igalinančias naudoti informaciją, pagerinant sveikatos priežiūrą ir pacientų saugumą;

26 Dumortier, J.; Verhenneman, G., supra note 6, p. 10-13.

27 Estonian Health Services Organisation Act [interaktyvus]. [žiūrèta 2013-12-25]. <https://www. riigiteataja.ee/en/eli/ee/512122013005/consolide>.

28 Dumortier, J.; Verhenneman, G., supra note 6, p. 12.

29 Country Brief Germany. eHealth Strategies Report. October, 2010 [interaktyvus]. [žiūrèta 2013-1225]. <http://ehealth-strategies.eu/database/germany.html>. 
- Skatinti informacinių technologijų naudojimą, gerinant paslaugas pacientams;

- Nustatyti efektyvią sveikatos sistemos informacijos valdymo struktūrą.

Šis įstatymas taip pat nustato pacientų teises prieiti prie elektroninių sveikatos įrašų informacijos. Šis įstatymas taip pat reglamentuoja visą gyvenimą galiojantị paciento identifikatorių, kuris sveikatos priežiūros tikslais identifikuoja pilietị, nepriklausomai nuo to, ar jis draustas, ar ne. Pagal ịstatymą, asmenys bet kokioje e. sveikatos įrašo sistemoje identifikuojami pagal vieną identifikatorių ${ }^{30}$.

Daugelio iš užsienio valstybių teisès aktai pakeisti, turint tikslą adaptuoti sveikatos duomenų tvarkymą elektronine forma ${ }^{31}$. Kaip vienas iš pavyzdžių paminėtina Danija, kuri tokius pakeitimus padarè 2007 metais. Buvo patikslintas sveikatos ịstatymas, kuris istoriškai reglamentavo, kad sveikatos duomenys tvarkomi ne elektroniniu, o popieriniu būdu. İ ịstatymą buvo įvestas naujas 42a straipsnis, reglamentuojantis elektroninių medicininių duomenų tvarkymą, taip pat konfidencialumą bei prieigos teises.

Taigi, nagrinètų užsienio valstybių ịstatymuose elektroninis sveikatos įrašas įtvirtintas kaip atskiras institutas.

Nagrinètina teisinio reguliavimo situacija Lietuvoje. Vienas iš pagrindinių ịstatymų Lietuvos Respublikos sveikatos sistemos įstatymas ${ }^{32}$, kuriame elektroninè sveikatos sistema reglamentuojama III skyriuje. Tam skirtas atskiras $13^{1}$ straipsnis „Lietuvos Respublikos elektroninès sveikatos sistemos valdymas“.

Visų pirma, straipsnio pirmojoje dalyje nustatyta, kad Lietuvos Respublikos elektroninès sveikatos sistemos ịgyvendinimą koordinuoja ir prižiūri Sveikatos apsaugos ministerija. Taigi, įstatymu už elektroninès sveikatos sistemos igyvendinimą paskirta viena atsakinga institucija.

Paaiškinama, kas yra laikoma elektroninès sveikatos sistema: Elektroninė sveikatos sistema (e. sveikatos sistema) - priemonių, skirtų sveikatinimo veiklai, pasitelkiant informacines ir ryšių technologijas, visuma ${ }^{33}$.

Antra, pagal minimo straipsnio antrąją dalį, igyvendinant Lietuvos Respublikos elektroninès sveikatos sistemos priemones, steigiama valstybės elektroninė sveikatos paslaugų ir bendradarbiavimo infrastruktūros informacinè sistema. Šios informacinès sistemos valdytoja yra Sveikatos apsaugos ministerija. Valstybės elektroninės sveikatos paslaugų ir bendradarbiavimo infrastruktūros informacinès sistemos nuostatus tvirtina ir tvarkytojus skiria Vyriausybė. Tai reiškia, kad įstatymu ịtvirtintas centralizuotas elektroninès sveikatos modelis, o Vyriausybei pavedama nustatyti detalias tokio modelio sąlygas.

Trečia, straipsnio trečiojoje dalyje ịtvirtinama pareiga naudotis valstybès elektronine sveikatos paslaugų sistema: visi LNSS sveikatinimo veiklos valdymo ir vykdomieji subjektai, sveikatos priežiūros paslaugas teikiantys ar gaunantys asmenys ir kiti asmenys, vykdydami teisès aktuose nustatytas funkcijas ar teikdami su sveikatinimo veikla susijusias paslaugas, privalo naudotis valstybès elektronine sveikatos paslaugų ir bendradarbiavimo infrastruktūros informacine sistema ir teisés aktų nustatyta tvarka teikti ir gauti duomenis.

Ketvirta, îstatymo straipsnio ketvirtoje dalyje nustatyti finansavimo principai: valstybès elektroninè sveikatos paslaugų ir bendradarbiavimo infrastruktūros informacinė sistema finansuojama iš valstybès biudžeto, Europos Sąjungos struktūrinių fondų, taip pat kitų teisès aktuose nustatytų finansavimo šaltinių.

30 Country Brief Ireland. eHealth Strategies Report. October, 2010, supra note 29.

$31 \quad$ Ibid., p. 15.

32 Lietuvos Respublikos sveikatos sistemos ịstatymas Nr. I-552 [interaktyvus]. [žiūrèta 2013-12-25]. $<$ http://www3.lrs.lt/pls/inter3/dokpaieska.showdoc_l?p_id=454090>.

$33 \quad$ Ibid., 2 str. 18 p. 
Tačiau įstatyme nèra įtvirtintų svarbių nuostatų dèl elektroninio sveikatos įrašo. Elektroninès sveikatos sistemos pagrindiniai požymiai, struktūra ir kiti svarbūs aspektai nèra įtvirtinti, paliekant tai padaryti Vyriausybei. Tačiau atkreiptinas dèmesys, kad tokie pamatiniai dalykai turi būti reglamentuoti istatymu. İstatymu reguliuojami svarbiausi visuomeniniai santykiai. Visuomeninių santykių „svarbumo“ kriterijus - individualios žmogaus teisès. İstatymais reguliuojama žmogaus teisių ir laisvių patvirtinimas, jų turinio apibrěžimas, apsaugos bei gynimo teisinès garantijos, leistinas jų apribojimas ${ }^{34}$. Kadangi teisè $\mathfrak{i}$ sveikatos apsaugą apibrěžiama kaip konstitucinè vertybe $\dot{e}^{35}$, manytina, kad minimo įstatymo normos turètų būti papildytos naujais aspektais, ịtvirtinančiais pamatinius e. sveikatos sistemos principus, struktūrą bei nustatančiais esminio e. sveikatos elemento - elektroninio sveikatos įrašo institutą.

Lietuvoje galioja ir dar vienas svarbus įstatymas - Lietuvos Respublikos pacientų teisių ir žalos sveikatai atlyginimo įstatymas ${ }^{36}$ - kuriame, be kitų institutų, yra numatytos bendrosios paciento teisès: teisè pasirinkti sveikatos priežiūros įstaigą ir sveikatos priežiūros specialistą; teisè ị informaciją; teisè nežinoti; teisè susipažinti su ịrašais savo medicininiuose dokumentuose; teise i privataus gyvenimo neliečiamumą; teisè ị anoniminę sveikatos priežiūrą.

Istatymo 7 straipsnyje reglamentuojama paciento teise susipažinti su įrašais savo medicininiuose dokumentuose. Šio straipsnio 1-ame punkte nurodyta: „paciento pageidavimu jam turi būti pateikti jo medicinos dokumentai“. 5-ame punkte nurodyta: „Pateikus asmens tapatybę patvirtinančius dokumentus, pacientui pageidaujant, jo lèšomis sveikatos priežiūros istaiga privalo padaryti ir išduoti sveikatos priežiūros įstaigos patvirtintas paciento medicinos dokumentu kopijas, taip pat išduoti diagnozès ir gydymo aprašymus“. Pažymètina, kad nei šios nuostatos, nei kitos įstatymo normos nenumato elektroninių sveikatos įrašų galimybès bei apskritai nepritaikytos elektroninei sveikatos sistemai.

Toks pats šiandienos realijų neatitinkantis įstatyme numatytas ir paciento sutikimo (įstatymo III skyrius) teisinis reguliavimas.

Kaip rodo užsienio valstybių teisinio reguliavimo praktika, pacientų teisės dažnai adaptuojamos elektroniniams sveikatos įrašams, reglamentuojant atitinkamose pamatinèse teisès normose. Todèl šiame ịstatyme reikalingi atitinkami pakeitimai.

\section{Privatumo ir asmens duomenų teisinė apsauga elektroninio sveikatos ịrašo atveju}

2013 m. Valstybinio audito ataskaitoje „Automatiniu būdu tvarkomų asmens duomenų apsauga" Nr. VA-P-90-3-21 nurodomos sritys, kuriose turètų būti daugiausiai dèmesio skiriama asmens duomenų apsaugai. Tarp nurodytų sričių trečioje vietoje sveikatos priežiūros veikla $^{37}$. Dar aktualesne ši sritis taps, kai Lietuvos Respublikoje bus daug plačiau pradèta naudoti elektroninius sveikatos įrašus. Siekiant užtikrinti tinkamą asmens duomenų apsaugą

\footnotetext{
$34 \quad$ Baublys, L., et al. Teisés teorijos įvadas. Vilnius: MES, 2010, p. 259.

35 Birmontas, V. Teise ị sveikatos priežiūros paslaugas kaip konstitucinè vertybè. Sveikatos politika ir valdymas. 2013, 1(5): 42.

36 Lietuvos Respublikos pacientų teisių ir žalos sveikatai atlyginimo ịstatymas. Nr. I-1562 [interaktyvus]. [žiūretta 2013-12-25]. <http://www3.lrs.lt/pls/inter3/dokpaieska.showdoc_l?p_id=458070>.

$372003 \mathrm{~m}$. gruodžio $23 \mathrm{~d}$. Valstybinio audito ataskaita „Automatiniu būdu tvarkomų asmens duomenų apsauga“ Nr. VA-P-90-3-21 [interaktyvus]. [žiūrèta 2013-12-20]. <http://www.vkontrole.lt/failas. aspx?id=3088>, 20 p.
} 
sveikatos sistemoje, ypač tvarkant asmens duomenis elektroniniu būdu, analizuotina, kaip dabartinis teisinis reguliavimas atitinka reikalavimus e. sveikatos sistemoms.

Reikia paminèti, kad siekiant panaikinti privatumo teisinès apsaugos reguliavimo skirtumus nacionalinėse valstybėse, ES ši sritis unifikuojama - taikoma bendroji duomenų apsaugos direktyva Nr. 95/46/EB ${ }^{38}$. Taigi, tiek visoje ES, tiek ir Lietuvoje reguliavimas iš principo turètų būti panašus. Vis dèlto konstatuojama, kad netgi igyvendinus bendrosios duomenų apsaugos direktyvą išliko tam tikrų nacionalinio reguliavimo skirtumų.

2008 m. patvirtintoje Europos Komisijos rekomendacijoje dèl tarpvalstybinio elektroninių sveiktos įrašų sistemų suderinamumo labai detaliai nurodoma, kokius požymius turi atitikti atitinkami teisès aktai ${ }^{39}$ :

a) Turi būti garantuotas asmens apsisprendimas, leidžiantis pacientui autonomiškai ir laisvai priimti sprendimą dèl asmens duomenų saugojimo elektroniniuose sveikatos i̇rašuose.

b) Elektroninių sveikatos įrašų sistemos turi būti kuriamos ir vystomos kaupiant kuo mažiau asmenị identifikuojančių duomenų.

c) E. sveikatos atveju, tvarkant asmens duomenis, iki elektroninio sveikatos ịrašo sistemos igyvendinimo turi būti vykdomas informacijos saugumo rizikų vertinimas ir ittaka asmens duomenų saugumui.

d) Turi būti aiškiai nustatyta asmens duomenų, prieinamų elektroniniu būdu arba online, apimtis. Genetinių duomenų tvarkymas online būdu turi būti apribotas, nebent būtų nustatytos specialios prieigos kontrolès priemonès.

e) Asmens duomenų tvarkymą elektroniniuose sveikatos įrašuose ir atitinkamose sistemose turi vykdyti tik sveikatos priežiūros darbuotojai, ịpareigoti išlaikyti asmens duomenų slaptumą.

f) Turi būti iggyvendintas patikimas pacientų ir sveikatos priežiūros sistemos darbuotojų identifikavimas.

g) Turi būti nustatytos teisètos prieigos prie sveikatos duomenų sąlygos.

h) Turi būti užtikrinta, kad pacientai būtų informuoti apie tvarkomus jų sveikatos duomenis ir apie elektroninio sveikatos įrašo struktūrą. Informacija pacientams turi būti lengvai suprantama ir aiški.

i) Turi būti užtikrinta, kad sveikatos duomenys būtų saugomi jurisdikcijoje, kurioje veikia duomenų apsaugos direktyva 95/46/EB.

Toliau bus analizuojama, kaip esamas privatumo teisinis reguliavimas atitinka anksčiau minètas Europos Komisijos rekomendacijas.

Asmens duomenų tvarkymą sveikatos apsaugos tikslais reglamentuoja Lietuvos Respublikos asmens duomenų teisinès apsaugos ịstatymas. Šiame įstatyme išskirtinas 10 straipsnis „Asmens duomenų tvarkymas sveikatos apsaugos tikslais“. Jame reglamentuojami igaliojimai tvarkyti asmens duomenis apie sveikatą, taip pat pareiga pranešti Valstybinei duomenų apsaugos inspekcijai apie asmens duomenų apie sveikatą tvarkymą bei pareigą atlikti išankstinę patikrą prieš tvarkant tokius duomenis. Visais kitais atvejais asmens duomenų apie sveikatą tvarkymą reglamentuoja bendrosios šio įstatymo normos.

38 Europos Parlamento ir Tarybos direktyva dèl asmenų apsaugos tvarkant asmens duomenis ir dèl laisvo tokių duomenų judèjimo Nr. 95/46/EB, 1995 [interaktyvus]. [žiūrèta 2013-12-28]. <http://eur-lex. europa.eu/LexUriServ/LexUriServ.do?uri=CONSLEG:1995L0046:20031120:LT:PDF>.

39 Commission Recommendation of 2 July 2008 on crossborder interoperability of electronic health record systems, supra note 3,14 p. a-1). 
Bendrosios teisès normos taikomos ir sutikimui tvarkyti asmens duomenis apie sveikatą. Lietuvos Respublikos asmens duomenų teisinès apsaugos įstatyme nustatyta, jog sutikimas savanoriškas duomenų subjekto valios pareiškimas tvarkyti jo asmens duomenis jam žinomu tikslu. Sutikimas tvarkyti ypatingus asmens duomenis turi būti išreikštas aiškiai - rašytine, jai prilyginta ar kita forma, neabejotinai ịrodančia duomenų subjekto valią ${ }^{40}$. Nors reikalavimai sutikimui e. sveikatos srityje ir nèra atskirai išskirti, bendrieji reikalavimai asmens sutikimui užtikrina apsisprendimo savanoriškumą. Bendrosios duomenų apsaugos direktyvos 29 straipsnio darbo grupés nuomoneje teigiama, kad opt-out ${ }^{41}$ sprendimai neatitinka reikalavimų, nustatytų sutikimui, įskaitant ir sutikimą tvarkyti asmens duomenis elektroninių sveikatos įrašų sistemose ${ }^{42}$. Tai reiškia, kad praktikoje gaunant atitinkamus sutikimus tiek visoje ES, tiek ir Lietuvoje turi būti taikomos opt-in sistemos ${ }^{43}$.

Tačiau paminètina, kad pagal Bendrąją duomenų apsaugos direktyvą, sutikimas nèra vienintele išimtis, taikoma bendrajam draudimui tvarkyti su sveikata susijusius asmens duomenis. Taip pat taikomos ir šios išimtys: esminių duomenų subjekto interesų išimtis; medicinos i̇staigų darbuotojų vykdomo duomenų tvarkymo išimtis; esminio viešojo intereso išimtis. Elektroninio sveikatos įrašo atvejui labai svarbi pastaroji išimtis, kuri, pagal direktyvos 29 straipsnio darbo grupès nuomonę, galètų būti taikoma: „elektroninių sveikatos įrašų sistemų įdiegimas galètų būti prilyginamas svarbiam visuomenės interesui “44. Pagal Lietuvos Respublikos asmens duomenų teisinès apsaugos įstatymą, norint pasiremti viešojo intereso išimtimi, reikètų taikyti įstatymo 6 straipsnio 1 dalies 6 punkto nuostatas.

E. sveikatos duomenų kaupimą reglamentuoja ịstatyme nustatyti asmens duomenų tvarkymo reikalavimai. Vienas iš reikalavimų - asmens duomenys turi būti tik tokios apimties, kuri būtina jiems rinkti ir toliau tvarkyti ${ }^{45}$. Šiuo reikalavimu igyvendinamas vienas iš duomenų kokybès principų, nustatytų ir Bendrojoje duomenų apsaugos direktyvoje Nr. 95/46/ EB. Taigi, galima teigti, kad yra užtikrinamas reikalavimas e. sveikatos sistemoje kaupti kuo mažiau asmens duomenų.

Rizikų vertinimo ir įtakos asmens duomenų saugumui reikalavimą (iki elektroninio sveikatos įrašo sistemos igyvendinimo) netiesiogiai nustato įstatymo nuostatos, ịpareigojančios ypatingų asmens duomenų ${ }^{46}$ atveju atlikti išankstinę patikrą. Atliekant išankstinę patikrą, vertinamos tiek rizikos, tiek įtaka asmens duomenų apie sveikatą saugumui. Tik atlikus išankstinę patikrą, duomenų valdytojas gali naudoti atitinkamą informacinę sistemą ir tvarkyti ypatingus asmens duomenis.

Istatymo 30 straipsnio 6 dalyje nustatyta, kad „Duomenu valdytojo, duomenu tvarkytojo ir ju atstovu darbuotojai, kurie tvarko asmens duomenis, privalo saugoti asmens duomenu

40 Lietuvos Respublikos asmens duomenų teisinès apsaugos ịstatymas Nr. I-1374 [interaktyvus]. [žiūrèta 2013-12-20]. <http://www3.lrs.lt/pls/inter3/dokpaieska.showdoc_l?p_id=400103>, 2 str. 12 p.

${ }^{41}$ Opt-out sistema reiškia, kad sutikimas yra numanomas ir asmens duomenys įtraukiami ị sistemą preziumuotinai, nebent duomenų subjektas išreiškia prieštaravimą.

42 Working document on the processinf of personal data relating to health in electronic health records (EHR). WP 131, supra note, 4, p. 9.

43 Opt-in sistema reiškia, kad prieš ịtraukiant asmens duomenis ị sistemą, reikalingas išankstinis duomenų subjekto sutikimas.

44 Working document on the processinf of personal data relating to health in electronic health records (EHR). WP 131, supra note 4, p. 13.

45 Lietuvos Respublikos asmens duomenų teisinès apsaugos ịstatymas Nr. I-1374, supra note 40, 3 str. 1 d. 4 p.

46 Asmens duomenys apie sveikatą pagal Lietuvos Respublikos asmens duomenų teisinès apsaugos įstatymą laikomi ypatingais asmens duomenimis. Jų tvarkymui yra taikomi griežtesni reikalavimai nei tvarkant paprastus asmens duomenis. 
paslaptị, jeigu šie asmens duomenys neskirti skelbti viešai“. Ši bendroji pareiga reiškia, kad asmens duomenų tvarkymą elektroniniuose sveikatos ịrašuose ir atitinkamose sistemose gali vykdyti tik sveikatos priežiūros darbuotojai, ịpareigoti išlaikyti asmens duomenų slaptumą.

Patikimas pacientų identifikavimas ${ }^{47}$ ir autentifikavimas ${ }^{48}$ elektroninių sveikatos įrašų sistemose yra kritiškai svarbus ${ }^{49}$. Nors Lietuvoje nėra privalomų pamatinių teisės normų, reglamentuojančių asmenų identifikavimą / autentifikavimą, paminètina Asmens duomenų teisinès apsaugos ịstatymo 30 straipsnio 2 dalis, kurioje nustatyta, kad „Valstybiné duomenu apsaugos inspekcija nustato bendruosius reikalavimus organizacinems ir techninems duomenu saugumo priemonèms". Bendruosius reikalavimus organizacinèms ir techninèms duomenu saugumo priemonėms Valstybinè duomenų apsaugos inspekcija patvirtino dar 2008 metais $^{50}$. Šiuose reikalavimuose yra ittvirtinti trys saugumo lygiai, kuriems yra nustatyti reikalavimai organizacinėms ir techninèms saugumo priemonėms. Aukščiausias saugumo lygis trečiasis lygis - „šiam saugumo lygiui priskirtas organizacines ir technines duomenų saugumo priemones turi užtikrinti duomenų valdytojai, automatiniu būdu tvarkantys ypatingus asmens duomenis duomenų bazèje (-se), prie kurios (-ių) yra prieiga per išorinius duomenų perdavimo tinklus ${ }^{\text {“51 }}$. E. sveikatos sistemos atitinka šio trečiojo lygio požymius. Visiems lygiams yra nustatytas reikalavimas užtikrinti prieigos prie duomenų valdymą ir kontrolę:

- prieiga prie asmens duomenų gali būti suteikta tik tam asmeniui, kuriam asmens duomenys yra reikalingi jo funkcijoms vykdyti;

- su asmens duomenimis galima atlikti tik tuos veiksmus, kuriems atlikti yra suteiktos teisès;

- užtikrintas slaptažodžių konfidencialumas juos suteikiant, pateikiant, reguliariai keičiant bei saugant, jeigu tapatybės patvirtinimas vykdomas naudojant slaptažodžius;

- turi būti užtikrintos organizacinès ir techninès duomenų saugumo priemonės, skirtos apsaugoti duomenų bazes nuo neteisèto prisijungimo elektroninių ryšių priemonèmis ${ }^{52}$.

Galima teigti, kad šiais reikalavimais yra užtikrinamas e. sveikatos sistemos darbuotojų identifikavimas jungiantis prie e. sveikatos sistemų. Nors tiesiogiai identifikavimas nèra minimas, kai kurios sąlygos siejamos su identifikavimo bei autentifikavimo elementais.

Galima kelti klausimą, kiek identifikavimą elektroninèje erdvèje būtina reguliuoti specialiomis teisés normomis (atskirais teisès aktais). Už minimalius identifikavimo reikalavimus elektronineje erdveje pasisako ir autoriai D. Štitilis, P. Pakutinskas, M. Laurinaitis, I. Dauparaitè mokslo monografijoje apie tapatybès vagystę elektroninèje erdveje, teigdami, kad valstybé turètų nustatyti minimalius indentifikavimo elektroninèje erdvejje reikalavimus $^{53}$. Manytina, kad valstybè turètų reguliuoti identifikavimą elektronineje erdvèje, ịskai-

47 Identifikavimas reiškia, kad asmuo gali būti apibūdinamas pagal identifikatorių, tokị kaip vardas, pavardé, gimimo data ir pan.

48 Autentifikavimas reiškia, įrodymą, kad asmuo, kuris siekia identifikavimo, yra būtent tas asmuo. Elektronineje erdveje autentifikavimas gali būti vykdomas naudojant elektroninị parašą.

49 Working document on the processinf of personal data relating to health in electronic health records (EHR). WP 131, 2007, supra note 4, p. 14.

50 Bendrieji reikalavimai organizacinèms ir techninèms duomenų saugumo priemonèms. Valstybinès duomenų apsaugos inspekcijos direktoriaus 2008 m. lapkričio 12 d. įsakymas Nr. 1T-71(1.12) [interaktyvus]. [žiūrèta 2013-12-21]. <http://www3.lrs.lt/pls/inter3/dokpaieska.showdoc_l?p_ $\mathrm{id}=331500 \& \mathrm{p} \_$tr $2=2>$.

$51 \quad$ Ibid., 7.3 p., Ibid., 9.2 p.

52 Ibid., $9.2 \mathrm{p}$.

53 Štitilis, D.; Pakutinskas, P.; Laurinaitis, M.; Dauparaitė, I. Tapatybės vagystè elektroninejje erdveje: socialiniai, elektroninio verslo ir teisinio reguliavimo aspektai. Kolektyvinè mokslo monografija. Vilnius: Mykolo Romerio universitetas, 2011, 150 psl. 
tant ir e. sveikatos sistemas, ir toks reguliavimas turètų būti ne įsakymu, o įstatymu arba (deleguojant) Vyriausybės nutarimu. Vis dèlto kol kas tokiu lygiu reguliavimo Lietuvoje nèra nustatyta.

Paminètina, jog Valstybinè duomenų apsaugos inspekcija yra patvirtinusi ir kitą poịstatyminị teisés aktą - Asmens tapatybès patvirtinimo elektronineje erdvẻje tvarkos aprašą ${ }^{54}$. Tačiau šio aprašo 1 punkte nustatyta, kad jis taikomas tik tuo atveju, kai elektroninių ryšių priemonėmis elektroniniai dokumentai pateikiami Valstybinei duomenų apsaugos inspekcijai. Taigi, aprašo taikymo sritis labai stipriai apribota.

Nors teisètos prieigos prie sveikatos duomenų sąlygos taip pat nèra reguliuojamos Lietuvos Respublikos asmens duomenų teisinès apsaugos ịstatyme, tačiau jau minètuose bendruosiuose reikalavimuose techninėms ir organizacinėms duomenų saugumo priemonems trečiajam lygiui yra ịtvirtintas ir toks reikalavimas - turi būti nustatyta prieigos teisių ir iggaliojimų tvarkyti asmens duomenis suteikimo, naikinimo ir keitimo tvarka. Taigi, poịstatyminiu teisés aktu duomenų valdytojai yra imperatyviai ịpareigoti nustatyti teisètos prieigos prie sveikatos duomenų sąlygas.

Duomenų subjekto informavimą apie tvarkomus sveikatos duomenis reglamentuoja Lietuvos Respublikos asmens duomenų teisinès apsaugos įstatymo 24 straipsnis „Duomenų subjekto informavimas apie jo duomenų tvarkymą“. Šiame straipsnyje detaliai nustatytos duomenų subjekto informavimo sąlygos, kurios taikomos ir elektroninių sveikatos įrašų atveju.

Reikalavimai sveikatos duomenis saugoti ES jurisdikcijoje netiesiogiai nustatyti Lietuvos Respublikos asmens duomenų teisinès apsaugos ịstatymo aštuntajame skirsnyje, kuriame reglamentuojamas asmens duomenų teikimas ị užsienio valstybes, ypač nesančias ES narèmis. Yra laikoma, kad ES asmens duomenys gali būti teikiami (įskaitant saugojimą) be apribojimų. Tačiau duomenų teikimui ị kitas valstybes yra nustatyti apribojimai. Todèl galima teigti, kad Lietuvoje yra nustatytas režimas, apribojantis duomenų teikimą ị trečiąsias valstybes.

Nepaisant dabar egzistuojančio teisinio reguliavimo privatumo ir asmens duomenų apsaugos srityje, paminètina, kad 2012 m. sausio 25 d. Europos Komisija pasiūlè visapusišką 1995 m. ES asmens duomenų taisyklių reformą, kad sustiprintų teises ị privatumą internete ir paskatintų Europos skaitmeninès ekonomikos augimą. Reformos ašis - Duomenų apsaugos reglamento projektas ${ }^{55}$. Paminètinos reglamento projekto nuostatos, susijusios su duomenų apie sveikatą tvarkymu. Reglamento 123 konstatuojamoje dalyje nustatyta, kad su sveikata susijusių duomenų, kuriems taikomi aukštesni apsaugos standartai, tvarkymas gali būti pateisinamas dèl ịvairių teisètų priežasčių, susijusių su asmens ir visos visuomenès interesais, ypač kai to reikia tarpvalstybinių sveikatos priežiūros paslaugų teikimo tęstinumui užtikrinti. Taigi, reglamentas galimai gali tiesiogiai nustatyti galimybę duomenis apie sveikatą rinkti ir be pacientų sutikimo (vadovaujantis teisètais interesais).

Be to, reglamento projekto 4 straipsnyje, kitaip nei galiojančioje Duomenų apsaugos direktyvoje, pateikiamas duomenų, susijusių su sveikata, apibrěžimas. Duomenys apie sveikatą reiškia bet kokią informaciją, susijusią su fizine ar psichine asmens sveikata, arba bet kokią informaciją apie sveikatos priežiūros paslaugų teikimą asmeniui. Šis apibréžimas yra

54 Asmens tapatybès patvirtinimo elektroninèje erdvejje tvarkos aprašas. Valstybinès duomenų apsaugos inspekcijos direktoriaus $2011 \mathrm{~m}$. birželio $17 \mathrm{~d}$. ịsakymas Nr. 1T-33(1.12) [interaktyvus]. [žiūrèta 201312-21]. <http://www3.lrs.lt/pls/inter3/dokpaieska.showdoc_l?p_id=402320\&p_tr2=2>.

55 Proposal for a Regulation of the European Parliament and of the Council on the protection of individuals with regards to the processing of personal data and on free movement of such data (General Data Protection Regulation). COM(2012)11 final, 2012 [interaktyvus]. [žiūrèta 2013-12-21]. <http:// ec.europa.eu/justice/data-protection/document/review2012/com_2012_11_en.pdf >. 
labai platus ir gali iš esmès apimti bet kurią informaciją apie pacientą. Taigi, reglamentas e. sveikatos srityje gali įnešti kelias naujoves. Kita vertus, reglamento nuostatos kol kas yra tik projektinès, dèl reglamento normų yra daug diskutuojama, tad galutinis reglamento tekstas gali būti pasikeitęs. Todèl reglamento projekto normos turi būti vertinamos atsargiai.

Apibendrinant galima teigti, kad Lietuvos Respublikos teisès aktai, kiek tai susiję su privatumo ir asmens duomenų teisine apsauga elektroninio sveikatos įrašo atveju, užtikrina tinkamą teisinę aplinką. Keltinas klausimas tik dẻl asmens identifikavimo teisinio reguliavimo perkèlimo ị aukštesnès galios teisès aktus. Naujasis duomenų apsaugos reglamento projektas galimai gali ịvesti kelias naujoves e. sveikatos srityje, tačiau šis projektas kol kas nepatvirtintas, jo nuostatos nèra galutinès.

\section{Kiti elektroninio sveikatos ịrašo teisinès aplinkos elementai}

Šiame straipsnyje buvo išnagrinèti kai kurie pagrindiniai, tačiau ne vieninteliai elektronini sveikatos ịrašo teisinès aplinkos elementai. Tiek užsienio autorių darbuose, tiek atitinkamose studijose nagrinėjami elektroninių sveikatos įrašų saugumo (duomenų pažeidimų, informavimo apie duomenų pažeidimus, skirtingų saugumo lygių), elektroninių sveikatos įrašų laikymo (angl. retention), pacientų e. teisių ị elektroninius sveikatos įrašus, elektroninių sveikatos įrašų teikimo ị kitas valstybes, elektroninių sveikatos įrašų gavimo iš kitų valstybių teisinio reguliavimo klausimai.

Kadangi elektroninio sveikatos įrašo teisinè aplinka dar tik vystosi, ateityje tiek mokslineje literatūroje, tiek praktinèse ir teorinèse studijoje bus nagrinėjamas dar platesnis teisinio reguliavimo klausimų spektras. Tuo tarpu autorius kai kuriuos elektroninio sveikatos įrašo teisinès aplinkos papildomus elementus galimai aptars kituose moksliniuose darbuose.

\section{Išvados}

1. Tiek ES, tiek užsienio valstybių strateginiuose e. sveikatos srities dokumentuose reglamentuojamas elektroninis sveikatos įrašas. Lietuvoje ši praktika taip pat egzistuoja: Lietuvos e. sveikatos strateginiuose dokumentuose elektroniniam sveikatos įrašui skiriama nemažai dèmesio, taip sukuriant pagrindą tolesniam teisiniam reguliavimui pamatinėmis ir kitomis normomis.

2. Europoje yra taikomi trys skirtingi elektroninio sveikatos ịrašo modeliai. Nagrinètų pasirinktų užsienio valstybių i̇statymuose, nepaisant pasirinkto modelio, elektroninis sveikatos įrašas yra ịteisintas kaip atskiras institutas.

3. Pamatinèse teisès normose Lietuvoje e. sveikatos sistemai skiriamas vienas straipsnis, kuris nustato kai kuriuos esminius e. sveikatos sistemos pagrindus. Lietuvoje pasirinktas centralizuotas e. sveikatos sistemos modelis, kuris dar vadinamas skandinaviškuoju modeliu. Deja, pamatinèse teisès normose Lietuvoje elektroninis sveikatos ịrašas kol kas specialiai nereglamentuojamas. Atsižvelgiant ị teisès teorijos tam tikrus principus bei užsienio šalių praktiką, Lietuvoje turètų būti priimtos papildomos ịstatymo normos elektroninio sveikatos ịrašo srityje.

4. Lietuvos Respublikos teisès aktai (kurie igyvendina ES duomenų apsaugos direktyvą Nr. 95/46/EB), kiek tai susiję su privatumo teisine apsauga elektroninio sveikatos įrašo atveju, užtikrina tinkamą teisinę aplinką. Nepaisant to, kad Lietuvoje yra poịstatyminès nuostatos dèl identifikavimo elektroninèse duomenų sistemose, šis reguliavimas turètų būti perkeltas ị įstatymo lygmenị (arba, deleguojant, reglamentuotas Vyriausybės nutarimu). Naujasis duomenų apsaugos reglamento projektas galimai gali ịvesti kelias naujoves e. sveikatos srityje, tačiau šis projektas kol kas nepatvirtintas, jo nuostatos nèra galutinès. 
5. ES duomenų apsaugos direktyva numato draudimą tvarkyti asmens duomenis apie sveikatą. Vis dèlto elektroninių sveikatos ịrašų sistemų ịdiegimas ir naudojimas galètų būti prilyginamas svarbiam visuomenės interesui (bendrojoje duomenų apsaugos direktyvoje nurodyta išimtis). Todèl diegiant elektroninių sveikatos įrašų sistemas, be asmens sutikimo, turètų būti galimybè praktikoje pasinaudoti ir šia išimtimi.

6. Be išnagrinètų elektroninio sveikatos įrašo teisinių problemų, aktualūs ir šie teisinio reguliavimo klausimai: elektroninių sveikatos įrašų saugumo (duomenų pažeidimų, informavimo apie duomenų pažeidimus, skirtingų saugumo lygių), elektroninių sveikatos įrašų laikymo (angl. retention), pacientų e. teisių ị elektroninius sveikatos įrašus, elektroninių sveikatos ịrašų teikimo ị kitas valstybes, elektroninių sveikatos įrašų gavimo iš kitų valstybių teisinio reguliavimo klausimai.

\section{Literatūra}

1. Asmens tapatybės patvirtinimo elektroninejje erdvèje tvarkos aprašas. Valstybinès duomenų apsaugos inspekcijos $2011 \mathrm{~m}$. birželio $17 \mathrm{~d}$. direktoriaus ịsakymas Nr. 1T33(1.12) [interaktyvus]. [žiūrèta 2013-12-21]. <http://www3.lrs.lt/pls/inter3/dokpaieska. showdoc_l?p_id=402320\&p_tr2=2>.

2. Baublys, L., et al. Teisés teorijos įvadas. Vilnius: MES, 2010.

3. Bendrieji reikalavimai organizacinèms ir techninèms duomenų saugumo priemonėms. Valstybinès duomenų apsaugos inspekcijos direktoriaus $2008 \mathrm{~m}$. lapkričio $12 \mathrm{~d}$. įsakymas Nr. 1T-71(1.12) [interaktyvus]. [žiūrèta 2013-12-21]. <http://www3.lrs.lt/pls/inter3/ dokpaieska.showdoc_l?p_id=331500\&p_tr2=2>;

4. Birmontas, V. Teisè ì sveikatos priežiūros paslaugas kaip konstitucinè vertybè. Sveikatos politika ir valdymas. 2013, 1(5).

5. Commission Recommendation of 2 July 2008 on crossborder interoperability of electronic health record systems [interaktyvus]. [žiūrèta 2013-11-28]. < http://eur-lex. europa.eu/LexUriServ/LexUriServ.do?uri=OJ:L:2008:190:0037:0043:EN:PDF>.

6. Communication from the Commission to the European Parliament, the Council, the European Economic and Social Committee and the Committee of the Regions „eHealth Action Plan 2012-2020 - Innovative healthcrefor the 21st century. Brussels, 6.12.2012, $\operatorname{COM}(2012) 736$ final [interaktyvus]. [žiūrèta 2013-11-28]. <http://eur-lex.europa.eu/ LexUriServ/LexUriServ.do?uri=COM:2012:0736:FIN:LT:PDF>.

7. Country Brief Germany. eHealth Strategies Report. October, 2010 [interaktyvus]. [žiūrèta 2013-12-25]. <http://ehealth-strategies.eu/database/germany.html>.

8. Country Brief Ireland. eHealth Strategies Report. October, 2010 [interaktyvus]. [žiūrèta 2013-12-25]. <http://ehealth-strategies.eu/database/documents/Ireland_CountryBrief_ eHStrategies.pdf $>$.

9. Dumortier, J.; Verhenneman, G. Legal regulations of electronic health record: a prerequisite or an unavoidable by-product? - The egal aspects of electronic health records in Europe and the US analysed. (December 22, 2011). ICRI Research Paper No. 5 [interaktyvus]. [žiūrèta 2013-11-28]. <http://papers.ssrn.com/sol3/papers.cfm?abstract_id=1975758>.

10. Estonian Health Services Organisation Act [interaktyvus]. [žiūrèta 2013-12-25]. <https:// www.riigiteataja.ee/en/eli/ee/512122013005/consolide>.

11. Europos Parlamento ir Tarybos 2011 m. kovo 9 d. direktyva 2011/24/ES dèl pacientų teisių i tarpvalstybines sveikatos priežiūros paslaugas igyvendinimo [interaktyvus]. [žiūrèta 2013-11-28]. <http://eur-lex.europa.eu/LexUriServ/LexUriServ.do?uri=OJ:L:201 1:088:0045:0065:lt:PDF>. 
12. Europos Parlamento ir Tarybos direktyva dèl asmenų apsaugos tvarkant asmens duomenis ir dèl laisvo tokių duomenų judejjimo Nr. 95/46/EB, 1995 [interaktyvus]. [žiūrèta 2013-12-28]. <http://eur-lex.europa.eu/LexUriServ/LexUriServ.do?uri=CONSL EG:1995L0046:20031120:LT:PDF>.

13. Gunter, T. D.; Terry, N. P. The Emergence of National Electronic Health Record Architectures in the United States and Australia: Models, Costs, and Questions. Journal of Medical Internet Research. 2005, 7(1) [interaktyvus]. [žiūrèta 2013-11-23]. <http:// www.ncbi.nlm.nih.gov/pmc/articles/PMC1550638/>.

14. Health Information: a National Strategy. Ireland, 2004 [interaktyvus]. [žiūrèta 2013-1128]. <http://www.dohc.ie/publications/pdf/nhis.pdf?direct=1>.

15. Kierkegaard, P. eHealth in Denmark: A Case Study. Journal of Medical Systems. 2013, October [interaktyvus]. [žiūrèta 2013-11-28]. <http://download.springer. com.skaitykla.mruni.eu/static/pdf/56/art\%253A10.1007\%252Fs10916-013-9991-y. pdf?auth66=1385807911_a0f9c2f3f540a719a82390f3871c7440\&ext=.pdf $>$.

16. Kierkegaard, P. Electronic health record: wiring Europe's healthcare. Computer law \& security review. 2011, 27 [interaktyvus]. [žiūrèta 2013-11-28]. <http://www.sciencedirect. com/science/article/pii/S0267364911001257>.

17. Lietuvos Respublikos asmens duomenų teisinès apsaugos ịstatymas Nr. I-1374 [interaktyvus]. [žiūrèta 2013-12-20]. <http://www3.lrs.lt/pls/inter3/dokpaieska. showdoc_l?p_id=400103>.

18. Lietuvos Respublikos elektroninio parašo įstatymo projekto paaiškinamasis raštas [interaktyvus]. [žiūrèta 2013-12-25]. <http://www3.lrs.lt/pls/inter3/dokpaieska. showdoc_l?p_id=101575>.

19. Lietuvos Respublikos pacientų teisių ir žalos sveikatai atlyginimo įstatymas Nr. I-1562 [interaktyvus]. [žiūrèta 2013-12-25]. <http://www3.lrs.lt/pls/inter3/dokpaieska. showdoc_l?p_id=458070>.

20. Lietuvos Respublikos sveikatos sistemos ịstatymas Nr. I-552 [interaktyvus]. [žiūrèta 2013-12-25]. <http://www3.lrs.lt/pls/inter3/dokpaieska.showdoc_l?p_id=454090>.

21. National Health Plan. Estonia [interaktyvus]. [žiūrèta 2013-12-16]. <http://www.sm.ee/ fileadmin/meedia/Dokumendid/Tervisevaldkond/Rahvatervis/RTA/ERTA_english.pdf>.

22. Proposal for a Regulation of the European Parliament and of the Council on the protection of individuals with regards to the processing of personal data and on free movement of such data (General Data Protection Regulation). COM(2012)11 final, 2012 [interaktyvus]. [žiūrèta 2013-12-21]. <http://ec.europa.eu/justice/data-protection/ document/review2012/com_2012_11_en.pdf>.

23. Sittig, D. F.; Singh, H. Legal, Ethical, and Financial Dilemmas in Electronic Health Record Adoption and Use. Pediatrics. 2011, 127(4) [interaktyvus]. [žiūrèta 2013-12-25]. <http://www.ncbi.nlm.nih.gov/pmc/articles/PMC3065078/>.

24. Štitilis, D.; Pakutinskas, P.; Laurinaitis, M.; Dauparaitè, I. Tapatybès vagystè elektroninèje erdvejje: socialiniai, elektroninio verslo ir teisinio reguliavimo aspektai. Kolektyvinè mokslo monografija. Vilnius: Mykolo Romerio universitetas, 2011.

25. Valstybinio audito ataskaita "Automatiniu būdu tvarkomų asmens duomenų apsauga“ Nr. VA-P-90-3-21, 2013 [interaktyvus]. [žiūrèta 2013-12-20]. <http://www.vkontrole.lt/ failas.aspx?id=3088>.

26. Working document on the processinf of personal data relating to health in electronic health records (EHR). WP 131, 2007 [interaktyvus]. [žiūrèta 2013-12-26]. <http:// ec.europa.eu/justice/policies/privacy/docs/wpdocs/2007/wp131_en.pdf>. 


\title{
Electronic Health Record and Legal Environment: Existing Situation and Problems
}

\author{
Darius Štitilis \\ Mykolas Romeris University, Lithuania
}

\section{Summary}

Electronic health record systems are becoming a reality. However, emerging electronic health record systems present numerous challenges, including challenges for legal systems. Therefore, the legal regulation of electronic health record is one of the most relevant problems in the sphere of e-health in the world, including Lithuania. So far, the analysis of legal problems related to electronic health record in scientific literature has been rather limited. Despite the fact that several foreign scientists have analysed electronic health records and the legal regulation, the author of this paper has not succeeded in finding any scientific article with analysis of Lithuanian legal regulation situation in the area of electronic health record.

The main goal of the thesis paper is to analyze and compare the legal regulation of electronic health record in the EU and several EU countries, including Lithuania. Special focus is put on strategical documents, legal status of electronic health record and protection of privacy and data protection and electronic health record.

Several different approaches have been used in the research. The author has used a comparative method to investigate the laws/legal frameworks and strategic documents of the EU, several EU countries, including Lithuania, in the area of electronic health records. The empirical analysis of legal documents was used to determine the legal regulation of the legal status of electronic health record and also to determine problems on privacy and data protection. Having analyzed the official documents, the method allows identifying and describing the relationship between the valid legal regulations accurately. Using literature resources, the author has used the deductive method, which allows drawing sufficiently reliable conclusions. The latest scientific literature and dictionaries have been used to study the definitions.

The article consists of four parts. The first part deals with the comparative aspect of strategic documents - the programs governing electronic health records in the EU, EU countries, including Lithuania.

The second part of the article examines the legal status of electronic health record in fundamental legal norms. It was found that there is a lack of Lithuanian law related to electronic health records.

The third part of the article examines legal protection of privacy and personal data in the case of using electronic health records. It was found that in principle, legal norms in Lithuania (which has implemented EU general data protection directive No. 95/46/EC) are enough to protect privacy and personal data of patients in electronic health records systems.

In the fourth part, the author mentions other main areas of legal regulation problems, related to electronic health records. Those problems need to be analysed in the nearest future.

Keywords: electronic health record, legal regulation.

Darius Štitilis, Mykolas Romeris University, Faculty of Social Technologies, Institute of Digital Technologies, Professor. Research interests: IT law, legal regulation of information technologies, legal regulation of e-health.

Darius Štitilis, Mykolo Romerio universiteto Socialinių technologijų fakulteto Skaitmeninių technologijų instituto profesorius. Mokslinių tyrimų kryptys: IT teisė, informacinių technologijų teisinis reguliavimas, e. sveikatos teisinis reguliavimas. 